\title{
Specific Activities of Natural Radionuclides in Beach Sand Samples from Samila Beach in Songkhla Province (Thailand) after Nuclear Power Plant Accident in Japan
}

\author{
Prasong Kessaratikoon, Ruthairat Boonkrongcheep, Nikom Choosiri, Nureda Taehdeng, and Suchin \\ Udomsomporn
}

\begin{abstract}
Specific activities of natural radionuclides $\left({ }^{40} \mathrm{~K}\right.$, ${ }^{226} \mathrm{Ra}$ and ${ }^{232} \mathrm{Th}$ ) in 30 beach sand samples collected from Samila beach of Songkhla province in southern region of Thailand, have been measured and evaluated. Experimental results were obtained by using a high-purity germanium (HPGe) detector and gamma spectrometry analysis system. The frequency distribution of specific activities of measured natural radionuclides $\left({ }^{40} \mathrm{~K},{ }^{226} \mathrm{Ra}\right.$ and $\left.{ }^{232} \mathrm{Th}\right)$ in all beach sand samples, have been also studied and analyzed. It was found that the frequency distribution of specific activities of ${ }^{40} \mathrm{~K},{ }^{226} \mathrm{Ra}$ and ${ }^{232}$ Th were asymmetrical distribution with the skewness of 2.50 , 4.28 and 4.11, respectively. The median values of ${ }^{40} \mathrm{~K},{ }^{226} \mathrm{Ra}$ and ${ }^{232} \mathrm{Th}$ were $868.51 \pm 118.42 \mathrm{~Bq} / \mathrm{kg}, 30.50 \pm 4.22 \mathrm{~Bq} / \mathrm{kg}$ and 23.31 $\pm 2.22 \mathrm{~Bq} / \mathrm{kg}$, respectively. Furthermore, four radiological hazard indices which are gamma-absorbed dose rate (D), radium equivalent activity $\left(\mathbf{R a}_{\mathrm{eq}}\right)$, external hazard index $\left(\mathrm{H}_{\mathrm{ex}}\right)$ and annual external effective dose rate $\left(A E D_{\text {out }}\right)$, were evaluated for Samila beach by using the median values of specific activities of ${ }^{40} \mathrm{~K},{ }^{226} \mathrm{Ra}$ and ${ }^{232} \mathrm{Th}$. Moreover, the results were also compared with the Office of Atoms for Peace (OAP) annual report data, Thailand and global radioactivity measurement and evaluations. From this study, the corresponding annual external effective dose rate $\left(\mathrm{AED}_{\text {out }}\right)$ was equal to $0.08 \pm 0.01 \mathrm{mSv} / \mathrm{y}$, significantly lower than the worldwide average as reported by United Nations Scientific Committee on the Effects of Atomic Radiation (UNSCEAR).
\end{abstract}

Index Terms-Beach sand, gamma spectrometry, natural radionuclide, radiological hazard index, specific activity.

\section{INTRODUCTION}

During the late $20^{\text {th }}$ and early $21^{\text {st }}$ century, one of the major interests in studies of natural background radiation is the requirement to set up reference levels, especially in areas

Manuscript received August 5, 2014; revised December 5, 2014. This work was fully supported by Office of the National Research Council of Thailand (NRCT) and Research and Development Institute Thaksin University (RDITSU).

P. Kessaratikoon, R. Boonkrongcheep, and N. Choosiri are with the Nuclear and Material Physics Research Unit (NuMPRU), Department of Physics, Faculty of Science, Thaksin University, Songkhla Campus, Muang, Songkhla, 90000 Thailand (e-mail: prasong_mi@hotmail.com, ruthairat.b@hotmail.com, nikom@tsu.ac.th).

N. Taehdeng is with Faculty of Education, Thaksin University, Songkhla Campus, Muang, Songkhla, 90000, Thailand (e-mail: n_da007@hotmail.com).

S. Udomsomporn is with the Office of Atoms for Peace (OAP) 16 Vibhavadi Rangsit Rd, Chatuchak, Bangkok, 10900, Thailand (e-mail: suchin@oaep.go.th). where the risk of radioactive material being released to environment is high e.g. in European countries and Japan after Chernobyl (1986) and Fukushima Dai-ichi (2011) nuclear power plant accidents, respectively. Furthermore, there is also a worldwide interest in identifying new areas with high natural radiation around the world. There are many scientists and researchers in several countries have studied the levels of natural background radiation by in situ measurements or by analysis of specific activities of natural radionuclides in soil or beach sand samples [1]-[7]. Moreover, radiological hazard studies have been made in beach sand samples in some famous beach locations, mainly in India and Brazil, because along theirs coastline there are quite a few monazite sand bearing placer deposits causing natural high background radiation areas [5], [8]-[11]. In Thailand, the levels of natural background radiation and radiological hazard assessment have been also studied in beach sand samples in different locations around the kingdom by some group of researchers [7], [12]-[14]. The present work was carried out in the Samila beach which is one of the most famous beaches in Songkhla province in the southern region of Thailand. The objective of this study was focused on studying the frequency distribution of specific activity of natural radionuclides $\left({ }^{40} \mathrm{~K},{ }^{226} \mathrm{Ra}\right.$ and $\left.{ }^{232} \mathrm{Th}\right)$ in beach sands samples collected from the Samila beach in Songkhla province. Furthermore, radiological hazard were also studied and evaluated for the investigated area. Moreover, the results were also compared with the Office of Atoms for Peace (OAP) annual report data, Thailand and global radioactivity measurement and evaluations.

\section{METHODOLOGY}

\section{A. Collection and Preparation of Beach Sand Samples}

30 Beach sand samples were collected along the Samila beach of Songkhla province in the south of Thailand. After collection, each sample was dried up at room temperature and sieved through a $2 \mathrm{~mm}$ mesh-sized sieve to remove stone, pebbles and other macro-impurities. All samples were oven dried at a temperature of $100{ }^{\circ} \mathrm{C}$ for 3 hours, before the analysis for removing moisture. The homogenized sample was placed in a PVC containers. The container was sealed hermitically and externally using a cellophane tape and kept aside for about a month to ensure equilibrium between ${ }^{226} \mathrm{Ra}$ and its daughters and ${ }^{228} \mathrm{Ra}$ and its daughters before being taken for gamma spectrometric measurement and analysis. 


\section{B. Measurement and Analysis the Specific Activity in Beach Sand Samples}

The specific activities of natural radionuclides $\left({ }^{40} \mathrm{~K},{ }^{226} \mathrm{Ra}\right.$ and ${ }^{232} \mathrm{Th}$ ) in all beach sand samples were determined by employing a high-purity germanium detector (HPGe, CANBERRA Model GC 2018) and gamma spectrometry analysis system at Nuclear and Material Physics Research Unit (NuMPRU), Department of Physics, Faculty of Science, Thaksin University, Songkhla Campus. The detector was enclosed in a massive $10 \mathrm{~cm}$ thick lead shielding. Geometric efficiency for beach sand matrices in the container was determined by the KCL, IAEA/RGU-1 and IAEA/RGTh-1 reference materials (International Atomic Energy Agency IAEA, Vienna, Austria). The spectra were analyzed using the program GENIE 2000. The specific activity of ${ }^{40} \mathrm{~K}$ was determined from its $1460 \mathrm{keV} \gamma$-line. The specific activities of ${ }^{226} \mathrm{Ra}$ and ${ }^{232} \mathrm{Th}$ were determined by their decay products ${ }^{214} \mathrm{~Pb}$ $(351.9 \mathrm{keV})$ and ${ }^{208} \mathrm{Tl}(583.2 \mathrm{keV})$, respectively. The specific activity of ${ }^{137} \mathrm{Cs}$ was also determined from its $661.7 \mathrm{keV}$ $\gamma$-line. The statistic computer program was employed to analyze the frequency distribution of specific activities of natural radionuclides $\left({ }^{40} \mathrm{~K},{ }^{226} \mathrm{Ra}\right.$ and $\left.{ }^{232} \mathrm{Th}\right)$ in all beach sand samples for the Samila beach of Songkhla province (Thailand). Four radiological hazard indices in these two beaches were also evaluated by using the appropriate medium values of the frequency distribution and the equations published in [9] and [11].

\section{RESULtS}

A. Frequency Distribution of Specific Activity of ${ }^{40} \mathrm{~K},{ }^{226} \mathrm{Ra}$ and ${ }^{232}$ Th in 30 Beach Sand Samples Collected from Samila Beach

By using the statistics computer program, the frequency distribution of specific activities of ${ }^{40} \mathrm{~K},{ }^{226} \mathrm{Ra}$ and ${ }^{232} \mathrm{Th}$ in 30 beach sand samples collected from Samila beach in Songkhla province (Thailand), were studied, analyzed and presented in the following Fig. 1 to Fig. 3.

B. Statistic Values of the Frequency Distribution of Specific Activities of ${ }^{40} \mathrm{~K},{ }^{226} \mathrm{Ra}$ and ${ }^{232} \mathrm{Th}$ in 30 Beach Sand Samples

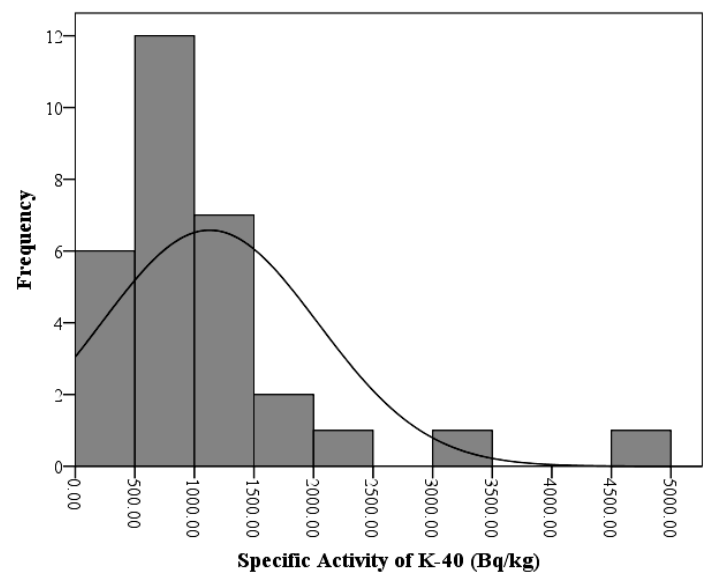

Fig. 1. Frequency distribution of specific activity of ${ }^{40} \mathrm{~K}$.

From Fig. 1 to Fig. 3 and all calculated statistic values, it was found that the frequency distribution of specific activities of ${ }^{40} \mathrm{~K},{ }^{226} \mathrm{Ra}$ and ${ }^{232} \mathrm{Th}$ in 30 beach sand samples collected from Samila beach in Songkhla province, were asymmetrical distribution with the skewness of 2.50, 4.28 and 4.11, respectively. For this reason, the median values of ${ }^{40} \mathrm{~K},{ }^{226} \mathrm{Ra}$ and ${ }^{232} \mathrm{Th}$ which were $868.51 \pm 118.42 \mathrm{~Bq} / \mathrm{kg}, 30.50 \pm 4.22$ $\mathrm{Bq} / \mathrm{kg}$ and $23.21 \pm 2.22 \mathrm{~Bq} / \mathrm{kg}$, for Samila beach, should be selected for calculation the corresponding radiological hazard evaluation in this area. The results were also compared with the Office of Atoms for Peace (OAP) annual report data, Thailand and global radioactivity measurement and evaluations as shown in Table I.

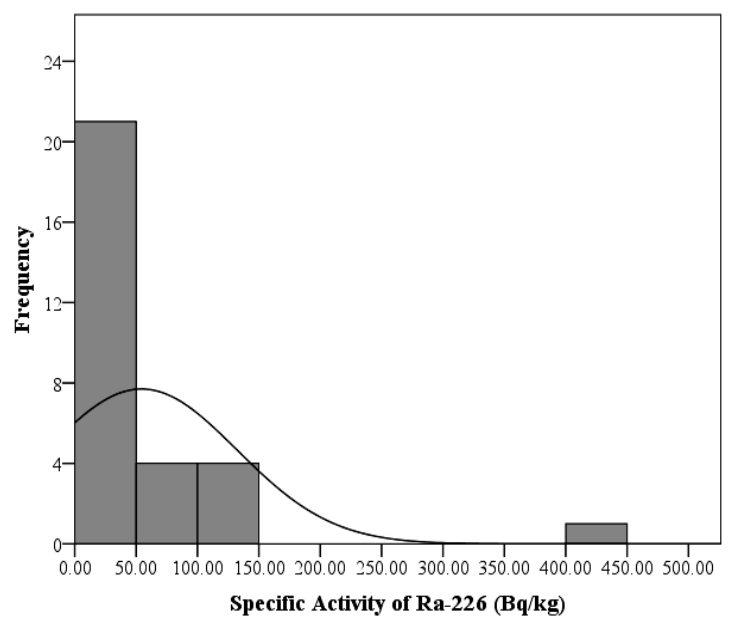

Fig. 2. Frequency distribution of specific activity of ${ }^{226} \mathrm{Ra}$.

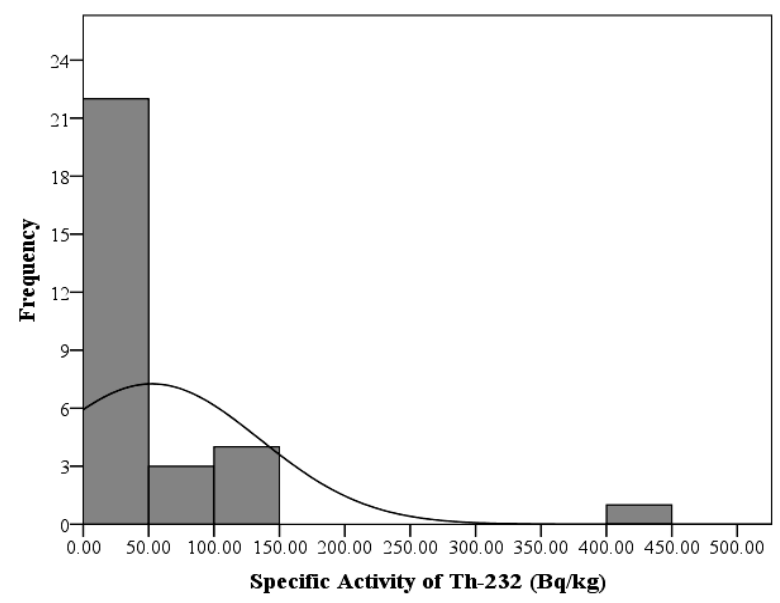

Fig. 3. Frequency distribution of specific activity of ${ }^{232} \mathrm{Th}$.

\section{Radiological Hazard Assessment}

Furthermore, four radiological hazard indices which are gamma absorbed dose rate (D), radium equivalent activity $\left(\mathrm{Ra}_{\mathrm{eq}}\right)$, external hazard index $\left(\mathrm{H}_{\mathrm{ex}}\right)$ and annual external effective dose rate $\left(\mathrm{AED}_{\text {out }}\right)$, were evaluated and presented in Table II for Samila beach by using the median values of specific activities of ${ }^{40} \mathrm{~K},{ }^{226} \mathrm{Ra}$ and ${ }^{232} \mathrm{Th}$. Moreover, the results were also compared with some research data in Thailand and UNSCEAR as shown in the same table.

\section{DISCUSSIONS}

According to Songkhla province is one of the province which is located in the eastern coast of Thailand, Samila 
beach certainly have the experiences of Naturally Occurring Radioactive Material (NORM) and Technologically Enhanced Naturally Occurring Radioactive Material (TENORM) activities e.g. phosphate fertilizers that are commonly used, oil and gas industry wastes and Fukushima Dai-ichi nuclear power plant accident. For this reason, the values of gamma absorbed dose rate in Samila beach were higher than about $1.2-3.7$ times to some research data in Thailand and UNSCEAR but lower than in Patong and Naiyang beaches in Phuket province. The values of radium equivalent activity in Samila beach were higher than about 1.6 - 3.6 times to some research data in Thailand but lower than in Patong and Naiyang beaches in Phuket province which is less than $370 \mathrm{~Bq} / \mathrm{kg}$, which are the acceptable value for safe use. The values of external hazard index obtained in this study were found to be $0.35 \pm 0.04$ for Samila beach which were less than unity. The calculated annual effective dose with average values $0.08 \pm 0.01 \mathrm{mSv} / \mathrm{y}$ for Samila beach were lower than the worldwide average value of $0.48 \mathrm{mSv} / \mathrm{y}$ as reported by UNSCEAR.

TABLE I: COMPARISON OF MEDIAN VALUES OF ${ }^{40} \mathrm{~K},{ }^{226} \mathrm{RA}$, AND ${ }^{232} \mathrm{TH}$ IN BQ/KG FOR SAMILA BEACH WITH THE OFFICE OF ATOMS FOR PEACE (OAP) ANNUAL REPORT DATA, THAILAND AND GLOBAL RADIOACTIVITY MEASUREMENT AND EVALUATIONS

\begin{tabular}{cccc}
\hline Locations & \multicolumn{3}{c}{ Specific Activity $(\mathrm{Bq} / \mathrm{kg})$} \\
\cline { 2 - 4 } & ${ }^{40} \mathrm{~K}$ & ${ }^{226} \mathrm{Ra}$ & $32.71 \pm 7.51$ \\
\hline Patong beach (Phuket province) & $3538.09 \pm 959.56$ & $29.72 \pm 11.48$ & $18.10 \pm 4.22$ \\
Naiyang beach (Phuket province) & $1648.27 \pm 702.98$ & $14.62 \pm 6.54$ & 5.78 \\
Ao Nang Beach (Krabi province) & 330.73 & 4.60 & 5.28 \\
Noppharat Thara beach (Krabi province) & 307.60 & 5.31 & 6.9 \\
Pakmeng beach (Trang province) & 57.3 & 23.1 & 23.53 \\
Chaweng beach (Surat Thani province) & 373.30 & 18.85 & $\mathbf{2 3 . 3 1} \pm \mathbf{2 . 2 2}$ \\
Samila beach (Songkhla province) & $\mathbf{8 6 8 . 5 1 \pm \mathbf { 1 1 8 . 4 2 }}$ & $\mathbf{3 0 . 5 0} \pm \mathbf{4 . 2 2}$ & $211.19 \pm 1.98$ \\
OAP (Southern region of Thailand) & $511.04 \pm 7.04$ & $171.55 \pm 3.13$ & 30 \\
Worldwide mean [17] & 400 & 35 & 30 \\
\hline \hline
\end{tabular}

TABLE II: COMPARISON BETWEEN THE CORRESPONDING RADIOLOGICAL HAZARD IN SAMILA BEACH WITH SOME RESEARCH DATA IN THAILAND AND UNITED NATIONS SCIENTIFIC COMMITTEE ON THE EFFECTS OF ATOMIC RADIATION (UNSCEAR)

\begin{tabular}{|c|c|c|c|c|}
\hline Locations & $\begin{array}{c}\text { D } \\
(\mathrm{nGy} / \mathrm{h})\end{array}$ & $\begin{array}{c}\mathrm{Ra}_{\mathrm{eq}} \\
(\mathrm{Bq} / \mathrm{kg})\end{array}$ & $\mathrm{H}_{\mathrm{ex}}$ & $\begin{array}{l}\mathrm{ADE}_{\text {out }} \\
(\mathrm{mSV} / \mathrm{y})\end{array}$ \\
\hline Patong beach (Phuket province) & $180.56 \pm 49.70$ & $348.93 \pm 96.11$ & $0.94 \pm 0.26$ & $0.22 \pm 0.06$ \\
\hline Naiyang beach (Phuket province) & $86.25 \pm 34.75$ & $167.42 \pm 66.70$ & $0.45 \pm 0.18$ & $0.11 \pm 0.04$ \\
\hline Ao Nang beach (Krabi province) & 19.41 & 38.33 & 0.10 & 0.02 \\
\hline Noppharat Thara beach (Krabi province) & 18.47 & 36.55 & 0.10 & 0.02 \\
\hline Pakmeng beach (Trang province) & 17.32 & 37.38 & 0.10 & 0.02 \\
\hline Chaweng beach (Surat Thani province) & 38.80 & 81.24 & 0.22 & 0.05 \\
\hline Samila beach (Songkhla province) & $64.54 \pm 8.23$ & $130.71 \pm 16.51$ & $0.35 \pm 0.04$ & $0.08 \pm 0.01$ \\
\hline UNSCEAR [15]-[17] & 55 & 370 & 1 & 0.48 \\
\hline
\end{tabular}

\section{CONCLUSIONS}

We can conclude that the monitored area (Samila beach) is at the typical level of radioactivity from natural background radiation after the Fukushima Dai-ichi nuclear power plant accident. Therefore, the radiological hazard is insignificant for the population living and spending sometimes in the investigated area.

\section{ACKNOWLEDGMENT}

The investigation is a part of research project which was fully supported by Office of the National Research Council of Thailand (NRCT) and Research and Development Institute Thaksin University (RDITSU). The authors wish to thank Assoc. Prof. Dr. Tripop Bhongsuwan, Department of Physics, Faculty of Science, Prince of Songkhla University (PSU), Hat Yai Campus for his generous permission to us to use all of standard reference materials for calculation and analysis in this research. The authors are particularly indebted to some of undergraduate and graduate students for their works and patience in samples collection, preparation, measurement and analysis some parts of these data.

\section{REFERENCES}

[1] S. Selvasekarapandian, R. Sivakumar, N. M. Manikandan, V. Meenakshisundaram, V. M. Raghunath, and V. Gajendran, "Natural radionuclide distribution in soils of Gugalore, India," Applied Radiation and Isotopes, vol. 52, pp. 299-306, February 2000.

[2] V. Kannan, M. P. Rajan, M. A. R. Iyenga, and R. Ramesh, "Distribution of natural and anthropogenic radionuclides in soil and beach sand samples of Kalpakkam(India) using hyperpure germanium (HPGe) gamma ray spectrometry," Applied Radiation and Isotopes, vol. 57, pp. 109-119, July 2002.

[3] A. K. Mohanty, D. Sengupta, S. K. Das, V. Vijayan, and S. K. Saha, "Natural radioactivity in the newly discovered high background radiation area on the eastern coast of Orissa, India," Radiation Measurements, vol. 38, pp. 153-165, April 2004.

[4] Y. K. Yang, X. M. Wu, Z. Y. Jiang, W. X. Wang, J. G. Lu, J. Lin, L. M. Wang, and Y. F. Hsia, "Radioactivity concentrations in soils of Xiazhuang granite area, China," Applied Radiation and Isotopes, vol. 63, pp. 255-259, August 2005.

[5] A. S. Alencar and A. C. Freitas, "Reference levels of natural radioactivity for the beach sands in a Brazilian southeastern coastal region," Radiation Measurements, vol. 40, pp.76-83, September 2005.

[6] E. M. Korobova, J. B. Brown, N. G. Ukraintseva, and V. V. Surkov, ${ }^{، 137} \mathrm{Cs}$ and ${ }^{40} \mathrm{~K}$ in the terrestrial vegetation of the Yenisey Estuary: landscape, soil and plant relationships," Journal of Environmental Radioactivity, vol. 96, pp. 145-156, July-September 2007.

[7] P. Kessaratikoon, R. Boonkrongcheep, S. Benjakul, and U. Youngchauy, "Specific activities and radioactive contour maps of natural and anthropogenic radionuclides in beach sand samples (Patong, Kamala, Kata, Karon and Nai Yang) after tsunami disaster in Phuket province, Thailand," Journal of Radioanalytical and Nuclear Chemistry, vol. 297, no. 2, pp. 247-255, August 2013.

[8] A. C. Freitas and A. S. Alencar, "Gamma dose rates and distribution of natural radionuclides in sand beaches-Ilha Grande, Southeastern Brazil," Journal of Environmental Radioactivity, vol. 75, pp. 211-223, 2004.

[9] S. Singh, A. Rani, and R. K. Mahajan, “ ${ }^{226} \mathrm{Ra},{ }^{232} \mathrm{Th}$ and ${ }^{40} \mathrm{~K}$ analysis in soil samples from some areas of Punjab and Himachal Pradesh, India 
using gamma ray spectrometry," Radiation Measurements, vol. 39, pp. 431-439, August 2005.

[10] D. Sengupta, A. K. Mohanty, S. K. Das, and S. K. Saha, "Natura radioactivity in the high background radiation area at Erasama beach placer deposit of Orissa, India," International Congress Series, vol. 1276, pp. 210-211, February 2005.

[11] R. Veiga, N. Sanches, R. M. Anjos, K. Macario, J. Bastos, M. Iguatemy, J. G. Aguiar, A. H. A. Santos, B. Mosquera, C. Carvalho, F. M. Baptista, and N. K. Umisedo, "Measurement natural radioactivity in Brazilian beach sands," Radiation Measurements, vol. 41, pp. 189-196, February 2006

[12] R. Boonkrongcheep, S. Benjakul, and P. Kessaratikoon, "Specific Activities and Radioactive Contour Maps of ${ }^{40} \mathrm{~K},{ }^{226} \mathrm{Ra},{ }^{232} \mathrm{Th}$ and ${ }^{137} \mathrm{Cs}$ in Beach Sand Samples From Muang District in Phuket Province (Thailand)," presented at the $6^{\text {th }}$ Annual Conference of the Thai Physics Society (SPC 2011), The Ambassador City Jomtien Hotel, Pattaya, Chonburi, Thailand, March 23-26, 2011.

[13] S. Chanyotha, C. Kranrod, S. Tokonami, N. Suwankot, K. Pangza, and C. Pornnumpa, "Terrestrial gamma radiation in Phuket Island, Thailand," Engineering Journal, vol. 15, no. 4, pp. 66-76, October 2011.

[14] D. Malain, P. H. Regan, D. A. Bradley, M. Matthews, H. A. Al-Sulaiti, and T. Santawamaitre, "An evaluation of the natural radioactivity in Andaman beach sand samples of Thailand after the 2004 tsunami," Applied Radiation and Isotopes, vol. 70, pp. 1467-1474, August 2012.

[15] Sources and Effects and Risk of Ionizing Radiation, United Nations Scientific Committee on the Effects of Atomic Radiation (UNSCEAR), United Nations, NY, 1988.

[16] Sources and Effects of Ionizing Radiation, United Nations Scientific Committee on the Effects of Atomic Radiation (UNSCEAR), United Nations, NY, 1993.

[17] Sources and Effects of Ionizing Radiation, United Nations Scientific Committee on the Effects of Atomic Radiation (UNSCEAR), United Nations, NY, 2000

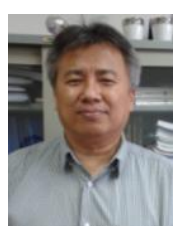

Prasong Kessaratikoon was born in Muang district, Chantaburi province, Thailand on October 31, 1961. He got the doctor of philosophy degree in physics from Old Dominion University, Virginia, USA in December, 2003; master of science degree in physics from Old Dominion University, Virginia, USA in May 1999 and master of science degree in physics from Chulalongkorn University, Bangkok, Thailand in July 1987; bachelor of edcation degree in science-physics and mathematics from Srinakharinwirot, Bangsaen, Chonburi, Thailand in April 1983

He was a lecturer and researcher in the Department of Physics Faculty of Science Srinakharinwirot Songkhla, Thailand from September 1987 to July 2010, and became an assistant professor from July 2010 to present in the Department of Physics Faculty of Science Thaksin University (TSU), Songkhla Campus, Muang, Songkhla, Thailand.

Dr. Kessaratikoon was the head of the Department of Physics from August 2005 to December 2008 and the deputy dean in Research and Graduate Study of Faculty of Science from December 2008 to December 2012, Thaksin University (TSU). He is the leader of Nuclear and Material Physics Research Unit (NuMPRU) which is organized and located in TSU, Songkhla, Thailand. He is also the member of Nuclear Society of Thailand (NST) and Thai Physics Society (TPS) in Thailand. He won the prize of excellent government officer award by Srinakharinwirot Songkhla University in 1990 and also won three honorable mention awards of the Thaksin University Best Thesis Award in Science and Technology in 2009 (1) and 2012 (2) in case of thesis Advisor by Graduate School Thaksin University (GSTSU).

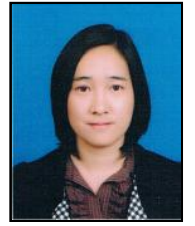

Ruthairat Boonkrongcheep was born in Muang district, Pattani province, Thailand on April 29, 1984. She got the master of Science degree in physics from Thaksin University, Songkhla, Thailand in June 2010, bachelor of science degree in physics from Thaksin University, Songkhla, Thailand in March 2007

She is a research assistant (RA) in Nuclear and Material Physics Research Unit (NuMPRU) Department of Physics Faculty of Science Thaksin University (TSU), Songkhla Campus, Muang, Songkhla, Thailand from December 2011 to present. She plans to study in doctoral program in Physics and Radiation Measurement in 2016.

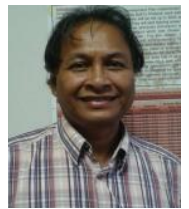

Nikom Choosiri was born in Ranot district, Songkhla province, Thailand on December 22, 1956. He got the doctor of philosophy degree in physics from Chulalongkorn University, Bangkok, Thailand in June, 1990; master of science degree in physics from Chulalongkorn University, Bangkok, Thailand in January 1984; bachelor of science degree in physics from Kasetsart University, Bangkok, Thailand in March 1980.

He was a lecturer and researcher in the Department of Physics, Faculty of Science, Srinakharinwirot Songkhla, Thailand from February 1984 to January 1998, and became an assistant professor from January 1998 to January 2001 in the Department of Physics, Faculty of Science, Thaksin University (TSU), Songkhla Campus, Muang, Songkhla, Thailand. He became the associate professor in TSU from January 2001 to present. He published the Fundamental Modern Physics books.

Dr. Choosiri was the head of the Department of Physics from 1996 to 1997. $\mathrm{He}$ is one of the research members of Nuclear and Material Physics Research Unit (NuMPRU) which is organized and located in TSU, Songkhla, Thailand. He is the editor in chief of Thaksin University Journal since 2002. He is also the member of Thai Physics Society (TPS) in Thailand. He won the best awards of the Thaksin University Best Thesis Award in Science and Technology in 2008 in case of thesis advisor and also won two honorable mention awards of the Thaksin University Best Thesis Award in Science an Technology in 2012 (2) in case of thesis Co-advisor by Graduate School Thaksin University (GSTSU).

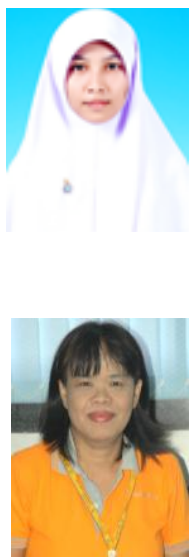

Nureda Taehdeng was born in Yarang district, Pattani province, Thailand on July 13, 1991.

She is a undergraduate student in bachelor of education (B.Ed.) Program in Science-Physics Faculty of Education Thaksin University (TSU), Songkhla Campus, Muang, Songkhla, Thailand. January 1985 to present.
Suchin Udomsomporn was born in Muang district, Pranakorn Sri Ayutthaya province, Thailand, on December 23, 1961. She got the master of science degree in environmental technology from Mahidol University, Bangkok, Thailand in May 2002; bachelor of science degree in physics from Ramkhamhaeng University, Bangkok, Thailand in March 1984.

She is a nuclear scientist in Office of Atoms for Peace 